Denis G. Privezentsev, Arcady L. Ziznyakov, Yaroslav Y. Kulkov DOI: 10.25045/jpit.v10.i2.06 Vladimir State University, Vladimir, Russia dgprivezencev@mail.ru

\title{
DEVELOPMENT OF THE FUZZY REPRESENTATION OF A DIGITAL IMAGE BASED ON A FRACTAL MODEL
}

\author{
Received: 21.12.2018 Revised: 27.02.2019 Accepted: 10.03.2019
}

The objective of the work is to improve the quality of digital image processing in vision systems by developing new features based on the use of fractal theory in conjunction with fuzzy logic and the theory of fuzzy sets. To develop a system of new features, a new model of digital image is needed. It is proposed to modify the fractal model by using a fuzzy distance in it as a measure of similarity of the image areas. This allows you to expand the hierarchy of representations of the source image, thereby increasing the amount of useful information about the original image. The modification of fractal attributes' system is proposed by using the membership function as the main metric, which allows using fuzzy logic in the formation of characteristic values. The proposed new model and a new system of features based on the use of fuzzy measures and membership functions will allow developing new image processing algorithms that differ from the existing possibility of using fuzzy conclusions and results.

Keywords: images processing, recognition, multiscale analysis, nanostructures.

\section{Introduction}

Most methods of digital image processing (including defectoscopic images) refer to one of two groups: spatial or frequency. Spatial methods make it possible to uniquely identify an object in an image, and frequency methods allow one to effectively analyse the spectral components of a two-dimensional signal (useful component and noise). In this case, spatial methods, as a rule, are subject to interference and require the source signal to be cleaned of noise, possibly with the loss of useful information. For frequency methods, the main problem is the localization of objects of interest in the coordinate system of the image.

The use of space-frequency approaches, for example, based on wavelet transforms, allows you to more accurately detect objects in images against background noise. This is due to the fact that the wavelet spectrum contains complete information about the original signal, including the spatial coordinates of the frequency components, and at the same time separates the useful and noise components.

However, the overwhelming majority of digital image processing algorithms are based on a clear algorithm for extracting useful information, which often does not allow the technical vision systems to solve non-trivial problems. In this regard, it is proposed to combine the mathematical theory of fuzzy sets and fuzzy logic with the proven fractal methods of digital image processing.

To develop a system of new features, a new model of digital image is needed. It is proposed to modify the fractal model developed by the project manager by using a fuzzy distance in it as a measure of similarity of the image areas. This allows to expand the hierarchy of representations of the original image, thereby increasing the amount of useful information about the original image.

With increasing complexity of the tasks being solved, it is expedient to use methods that are specially oriented to the construction of models, methods and algorithms that take into account the incompleteness and inaccuracy of the initial data. It is in such situations that the theory of fuzzy sets and fuzzy logic proves to be the most constructive. Already achieved theoretical results allow considering fuzzy logic as a promising tool for the analysis of heterogeneous information, in the form of complex qualitative linguistic descriptions and quantitative data. In modern works, methods and algorithms for using fuzzy logic and fuzzy-set theory are considered to solve problems of digital image processing.

Analysis of the used fuzzy image processing schemes [1-3] shows that the used fuzzy representations of images, as well as the membership functions used to translate images into fuzzy 
forms, do not have a single mathematical basis. Used fuzzy signs and properties of images are built on the representation of images in the form of sets. In this case, there is no possibility of sharing fuzzy technologies with classical algorithms of digital image processing. A number of papers describe fuzzy measures, fuzzy integrals that are used in segmentation and clustering problems as local statistical features that are defined on the set to which the image is represented [4]. From this it follows that a system of fuzzy signs, measures and distances that will allow developing new algorithms for digital image processing is needed for the joint use of classical features, measures and algorithms in conjunction with fuzzy imaging technologies.

In connection with the foregoing, it is proposed to develop a fuzzy mathematical model of a digital image based on its description by the terms of fuzzy sets using fuzzy logic, which is the basis for constructing new algorithms for extracting information about features and image processing algorithms.

\section{Fractal model of digital image}

The fractal model of the digital image developed and described in [5-7] implements the system of iterated functions and can be represented by the expression

$$
f^{\prime}=\sum_{i=1}^{n}\left(B_{n_{i}, m_{i}}^{r_{i}}\right)^{*}\left[S_{i}\left(\widetilde{w}\left(B_{k_{i}, l_{i}}^{d_{i}}\right)[f]\right)+o_{i}\right]
$$

where

$$
D=\left(B_{k_{i}, l_{i}}^{d_{i}}\right)[f] .
$$

is an operator of extracting a domain block with the index di from the original image $f$. The transformation that performs the change in the colour characteristics of the domain block and the geometric transformation has the following formula

$$
D^{\prime}=s_{i}(w[D])+o_{i} .
$$

After all the transformations are performed on the original domain block, the result is inserted into the image

$$
f^{\prime}=\sum_{i=1}^{M}\left(B_{n_{i}, m_{i}}^{r_{i}}\right)^{*}\left[D^{\prime}\right] .
$$

Using 1, 2 and 3, formulate an expression describing the range block of the image through the domain block

$$
R_{i}=D^{\prime}=s_{i}(w[D])+o_{i} .
$$

For comparison of two images $\mathrm{f}, \mathrm{h}$ metric used RMS:

$$
g(f, h)=\sum_{i, j} \sqrt{\frac{1}{m \cdot n}[f(i, j)-h(i, j)]^{2}},
$$

where $m, n-$ is the size of the images. For each range block of the image $R_{i}$, the domain block $D_{i}$ is selected which best approximates the range block. In other words, there is a pair $\left(R_{i}\right.$; $\mathrm{D}_{\mathrm{j}}$ ) for which the metric (6) is minimal.

To generate a fractal image code, a quadruped of range blocks is used. The root of the tree is the image itself.

Expression 5 can be represented as follows

$$
\begin{aligned}
R_{i}=D^{\prime}+ & \xi_{i}, \\
& \xi_{i}=g\left(R_{i}, D^{\prime}\right) .
\end{aligned}
$$

In other words, the fractal model describes the original image using quadrates. Each leaf of 
a tree is a range block of the image, which corresponds to a domain block so that the approximation error is minimal.

\section{Intuitionistic fuzzy set}

A fuzzy set $\mathrm{A}$ in a finite set $X=x_{1}, x_{2}, \ldots, x_{n}$ may be represented mathematically as

$$
A=\left\{\left(x, \mu_{A}(x)\right) \mid x \in X\right\},
$$

where the function $\mu_{A}(x): X \rightarrow[0,1]$ is the measure of the degree of belongingness or the membership function of an element $\mathrm{x}$ in the finite set $\mathrm{X}$.

An Intuitionistic Fuzzy Set A in a finite set X may be mathematically represented as

$$
A=\left\{\left(x, \mu_{A}(x), v_{A}(x)\right) \mid x \in X\right\},
$$

where the functions $\mu_{A}(x), v_{A}(x): X \rightarrow[0,1]$ are, respectively, the membership function and the non-membership function of an element $x$ in a finite set $X$ with the necessary condition

$$
0 \leq \mu_{A}(x)+v_{A}(x) \leq 1 .
$$

It is clear that every fuzzy set is a particular case of IFS:

$$
A=\left\{\left(x, \mu_{A}(x), 1-\mu_{A}(x)\right) \mid x \in X\right\} .
$$

\section{Development of fuzzy fractal model}

To use all the features of fuzzy sets is necessary to modify the model (5) and bring it to the fuzzy mind. During the construction of the fractal image code, a set of range blocks, domain blocks and approximation error values are generated:

$$
R=\left\{R_{i}\right\}, R_{i}=\left\{D_{j}, \xi_{i, j}\right\} .
$$

Then, using 8, expression 9 can be expressed using a fuzzy set

$$
R=\left\{D_{j}, \mu_{R}\left(D_{j}\right), 1-\mu_{R}\left(D_{j}\right) \mid D_{j} \in D\right\} .
$$

Then the membership function $\mu_{R}\left(D_{j}\right)$ may be represented as

$$
\mu_{R}\left(D_{j}\right)=\frac{\xi_{j}}{\xi_{\max }},
$$

where $\xi_{\max }$ is the maximum approximation error, which is defined as the difference between absolutely black and absolutely white images:

$$
\xi_{\text {max }}=\frac{255}{\sqrt{m \cdot n}},
$$

where $m, n-$ is the image size.

Let the image $\mathrm{f}$ is a graph $G=(V, U)$, where $\mathrm{V}$ is the list of range blocks of the image, $U$ is the connections between the range blocks. Then the process of forming a tree of range blocks of the image can be described as follows. There is a range block of zero level $\mathrm{R}^{0}$, which corresponds to the whole image and $\mathrm{v}_{1}=\mathrm{R}^{0}$. It contains range blocks of the first level $R_{1}^{1}, R_{2}^{1}, R_{3}^{1}, R_{4}^{1} \in R^{0}$ :

$$
v_{2}=R_{1}^{1}, v_{3}=R_{2}^{1}, v_{4}=R_{3}^{1}, v_{5}=R_{4}^{1},
$$




$$
\bar{u}_{1}=\left(v_{1}, v_{2}\right), \bar{u}_{2}=\left(v_{1}, v_{3}\right), \bar{u}_{3}=\left(v_{1}, v_{4}\right), \bar{u}_{4}=\left(v_{1}, v_{5}\right) \in \bar{U},
$$

Continuing the formation of the fractal code, a complete tree of range blocks is obtained, from which the image is constructed. A fragment of the tree of range blocks is shown in figure. 1.

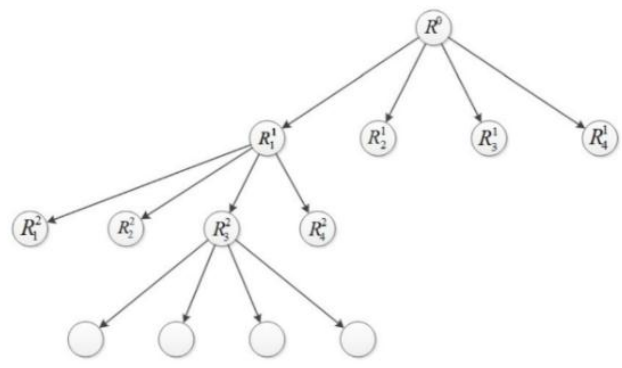

Figure 1. Fragment of the tree of range blocks

The operator for the formation of a fractal code is called a direct fractal transformation:

$$
F(f, D)=\Phi,
$$

where $\Phi$ is the resulting fractal code of the image $f$ by the operator F. An additional parameter of the operator is the list of domain image blocks D involved in the code generation. There is an inverse fractal transformation that forms the image by the fractal code:

$$
f^{\prime}=F^{*}(\Phi, D)=F^{*}(F(j, D)) \text {. }
$$

To properly restore an image from its fractal code, it is important that the transformations use the same list of domain blocks D. In the original version, the generated fractal code is complete. This means that each vertex of the graph has one parent and four descendants, but the length of the descending chain does not exceed the depth of the quad, which is specified at the initial stage of the code construction. If the full tree is used as the parameter for restoring the image by the operator 12, then the image $\mathrm{f0}$ will be as similar as the original image.

For obtaining modified images, incomplete trees of range blocks are used. To form an incomplete tree, use the operator that can be represented as:

$$
\Phi^{*}=\Gamma(\Phi) \text {. }
$$

The form of the operator $\Gamma$ depends on the required result. For example, by removing some branches of a fractal tree, you can obtain an image in which the areas for which remote branches respond are smoothed and the remaining areas are clear. Using 10, the threshold operator $\Gamma$ can be represented as:

$$
\Gamma(\Phi)=\left\{R^{\prime}, D\right\}, R^{\prime}=\left\{R_{i} \mid \mu_{R}\left(D_{j}\right)>\varepsilon\right\} .
$$

The operator 14 allows us to use only range blocks with a value of the membership function greater than the given threshold . .

To obtain a fractal representation of the image from the fractal code, the leaves of the tree are removed. The result is a smoothed, fractal image. Figure 2 depicts an example of such decomposition of a test image. The resulting set of images allows for a more detailed analysis of the original image. The transition to other scales allows you to move away from small and random details, it is better to reveal the "internal" structure. It is of interest to consider the structural elements allocated at different scales of the representation of the image. 


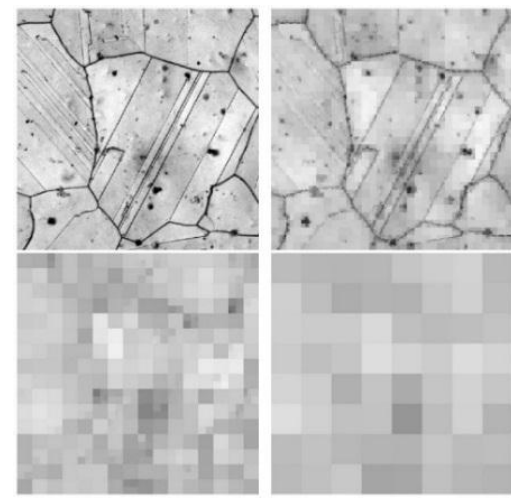

Figure 2. Fractal fuzzy representation of a test image

The reason for this approach is as follows. Structural elements of the image, such as contours, segments, skeleton, basically carry all the meaningful information about the original image. At the same time, they have a much more compact representation and are better suited for analysis, both automatic and subjective, than the original halftone image. In the case of automatic analysis, it is determined by the possibility of a formal description of the structural elements, for example, the parameters of the curve (for the contour, the skeleton) or the area geometric object (for segmentation).

\section{Conclusion}

The fractal image code can be represented in the form of a graph $\mathrm{G}$, in which the vertices of $\mathrm{V}$ are range blocks $\mathrm{R}$, and the arcs are the nestedness relations of range blocks. At the same time, the structure of the code remains unchanged, this approach changes only the form of representation and the mathematical apparatus of research.

The described approach to the fractal representation of images can be used to form a set of features reflecting the internal structure of the image, since small details are discarded. Further on, based on the proposed description, algorithms for isolating contours, image segmentation, skeletonization, etc. can be constructed. This supports the usability of the proposed algorithm in practical problems of non-destructive testing.

Also new fractal attributes of digital images - characteristic sites are offered. These signs show which parts of the image are involved in its formation, i.e. according to the self-similarity distribution within the image, it is possible to identify areas using which you can reproduce the image with the greatest accuracy. An algorithm is developed for searching for areas of the image that are not characteristic of this class of images. The algorithm is based on the fact that uncharacteristic areas of the image are poorly approximated by the characteristic sections of this class of images.

\section{Acknowledgements}

The reported study was funded by RFBR according to the research project №17-47-330073.

\section{References}

1. Mario I. Chacon M. Fuzzy Logic for Image Processing: Definition and Applications of a Fuzzy Image Processing Scheme // Advanced Fuzzy Logic Technologies in Industrial Applications, 2006, pp.101-113.

2. Tamalika Chaira. Fuzzy Measures in Image Processing // Fuzzy Sets and Their Extensions: Representation, Aggregation and Models, 2008, pp.587-606.

3. Chi Z., Yan H., Pham T. Fuzzy algorithms: With Applications to Image Processing and Pattern Recognition / Singapore, New Jersey, London, Hong Kong: Word Scientific, 1998, 225 p.

4. Bing-Yuan Cao, Fuzzy Cluster Analysis and Fuzzy Recognition // Optimal Models and Methods with Fuzzy Quantities Studies in Fuzziness and Soft Computing, 2010, vol.248, pp.117-137.

5. Zhiznyakov A.L., Privezentsev D.G., Zakharov A.A. Using fractal features of digital images for the 
detection of surface defects // Pattern Recognition and Image Analysis (Advances in Mathematical Theory and Applications), 2015, vol.25, no.1, pp.122-131.

6. Privezentsev D.G., Zhiznyakov A.L. Use of characteristic image segments in tasks of digital image processing / 2015 International Conference "Stability and Control Processes" in Memory of V.I. Zubov (SCP), 2015, pp.659-660.

7. Zhiznyakov A.L., Privezentsev D.G., Pugin E.V. Use of fractal signs of digital images for detection of surface defects / CriMiCo 2014 - 2014 24th International Crimean Conference Microwave and Telecommunication Technology Conference Proceedings, 2014, pp.391-392.

\section{UOT 004.93}

Privezentsev Denis Q., Jiznyakov Arkadiy L., Kulkov Yaroslav Y.

Vladimir Dövlət Universiteti, Vladimir, Rusiya

dgprivezencev@mail.ru

Fraktal modelə əsaslanan rəqəmsal görüntünün qeyri-səlis təsviri

İşin əsas məqsədi qeyri-səlis məntiq və qeyri-səlis nəzəriyyəyə istinad etməklə fraktal nəzəriyyə əsasında yeni xüsusiyyətlər işləməklə rəqəmsal şəkil emalının baxış sistemlərində keyfiyyəti artırmaqdır. Şəkil sahələri arasında ölçü oxşarlığını ölçmək üçün qeyri-səlis məsafədən istifadə etməklə modifikasiya olunmuş fractal model təklif olunur. Bu da orijinal şəkil barədə faydalı məlumatları artırmaqla mənbə şəklinin təsvirinin iyeararxiyasını genişləndirməyə imkan verir. Fraktal xüsusiyyətlərin sisteminin mənsubiyyət funksiyasını əsas metrika kimi istifadə etməklə modifikasiyası təklif olunur, bu da xarakterik dəyərlərin formalaşmasında qeyri-səlis məntiqdən istifadə etməyə imkan verir. Təklif edilən yeni model və qeyri-səlis ölşü və mənsubiyyət funksiyalasının tətbiqinə əsaslanan yeni bir sistem qeyrisəlis nəticələrdən istifadə imkanlarından fərqli olan yeni görüntü emal alqoritmlərinin işlənilməsinə imkan verir.

Açar sözlor: görüntülarin emalı, görüntülarin tanınması, çoxmiqyaslı analiz, nanostrukturlar.

\section{УДК 004.93}

\section{Привезенцев Денис Г., Жизняков Аркадий Л., Кульков Ярослав Ю.}

Владимирский государственный университет, Владимир, Россия

dgprivezencev@mail.ru

Нечеткое описание цифрового изображения на основе фрактальной модели

Целью работы являются повышение качества обработки цифровых изображений в системах зрения путем разработки новых функций, основанных на фрактальной теории, связанных с нечеткой логикой и теорией нечетких множеств. Для разработки системы новых функций необходима новая модель цифрового изображения. Предлагается модифицировать фрактальную модель, используя нечеткое расстояние в ней как меру сходства областей изображения. Это позволяет расширить иерархию представлений исходного изображения, тем самым увеличив объем полезной информации об исходном изображении. Систему фрактальных атрибутов предлагается модифицировать, используя функцию принадлежности в качестве основной метрики, что позволяет использовать нечеткую логику при формировании характеристических значений. Предложенная новая модель и новая система функций, основанные на использовании нечетких мер и функций принадлежности, позволят разработать новые алгоритмы обработки изображений, которые отличаются от существующей возможности использования нечетких выводов и результатов.

Ключевые слова: обработка изображений, распознавание изображений, многомасмтабный анализ, наноструктуры. 